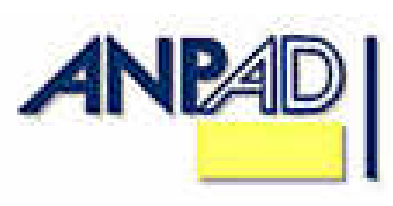

Available online at

http://www.anpad.org.br/bar

\title{
Cause Related Marketing: Consumers' Perceptions and Benefits for Profit and Non-Profits Organisations
}

\author{
Francisca Farache * \\ E-mail address: ffads@brighton.ac.uk \\ Brighton Business School, University of Brighton \\ Brighton, England.
}

\section{Keith John Perks}

E-mail address: K.J.Perks@bton.ac.uk

Brighton Business School, University of Brighton

Brighton, England.

\section{Lilian Soares Outtes Wanderley}

E-mail address: lilian.wanderley@ufpe.br

Programa de Pós-Graduação em Administração, Universidade Federal de Pernambuco

Recife, PE, Brazil.

\section{José Milton de Sousa Filho}

E-mail address: miltonsousa@gmail.com

Programa de Pós-Graduação em Administração, Universidade Federal de Pernambuco Recife, PE, Brazil.

\begin{abstract}
This study is an attempt to understand consumers' perceptions regarding Cause Related Marketing [CRM]. The research findings were based on a survey of 200 consumers in the Brighton area and published data. The research aim was focused on the consumers' perception of the alliance between corporations and non-profit organisations. The research found that consumers have a better perception of firms that work with charities and good causes than those that do not. They believe that the partnership between corporations and charities has an impact on the good of society. However, they are aware that corporations themselves benefit from this partnership. Concerning good causes, consumers prefer to support those related to Children. The researchers noticed that an individual connection with a cause might have considerable influence on consumer attitudes and behaviour in relation to a specific cause.
\end{abstract}

Key words: cause related marketing; corporate social responsibility; consumer behavior; third sector.

Received 09 November 2007; received in revised form 20 June 2008.

Copyright (C) 2008 Brazilian Administration Review. All rights reserved, including rights for translation. Parts of this work may be quoted without prior knowledge on the condition that the source is identified.

*Corresponding author: Francisca Farache

Brighton Business School, Mithras House, Lewes Road, Brighton BN2 4AT, England. 


\section{INTRODUCTION}

Because of growing public concern over environmental and social issues, corporations have begun to affiliate their products with a range of popular causes, including social and ecological issues (Yechiam, Barron, Erev, \& Erez, 2002). Linking themselves to good causes has become attractive to many businesses, especially those engaged in dealings with consumers (Till \& Nowak, 2000). These associations can influence perceptions regarding the corporation and, consequently, have an effect on how consumers evaluate products or services offered by the corporation (Brown \& Dacin, 1997).

In this scenario, Cause Related Marketing [CRM] is a means of demonstrating a corporation's social commitment. CRM evolved as a marketing strategy utilized by business to form a partnership for mutual benefit with a charity organisation or a good cause (Pringle \& Thompson, 1999). Since the beginning of CRM in the early 1980's, the number of alliances between for-profits and non-profits has been steadily increasing (Adkins, 2000). The constant growth in this area is as a result of the positive experience of corporations in their CRM programmes (Barone, Miyazaki, \& Taylor, 2000). The Business in the Community (2003), states that in 2003 over $£ 58$ million was raised by over 60 businesses benefiting over 60 charities and good causes through more than 80 CRM programmes in the UK. In the United States, American corporations dedicated U\$ 9 billion to social causes in 2001 alone (Cone, Feldman, \& DaSilva, 2003).

CRM strategies have helped corporations enhance their reputation and corporate image, strengthen ties with employees and increase sales and profits (Adkins, 2000; Drumwright, 1996; File \& Prince, 1998; Kotler, 2003; Pringle \& Thompson, 1999). The corporations are not alone in reaping the benefits of this process; charities and social causes also profit through financial gains and support (Docherty \& Hibbert, 2003; Polonsky \& Wood, 2001). Furthermore, CRM programmes give free publicity, PR and public awareness not only to the cause but also to the for-profit organisation (Andreasen, 1996; Wood, 1998).

Despite the benefits to the corporations and non-profits, the level of customer awareness, participation and commitment is a crucial component of CRM (Broderick, Jogi, \& Garry, 2003). The attitudes and perceptions of consumers are vital to the success of CRM programmes (Adkins, 2000). Consumer surveys can help corporations to identify where and how they should position their product or service in relation to increased sales, brand awareness, corporate reputation and customer loyalty. Similarly, managers and marketers must ensure that their corporate activities are perceived as responsible from the consumer perspective (Endacott, 2004).

While corporations are concerned with profits and reputation, Consumer Associations worldwide are concerned with environmental and social issues, human rights, consumer rights, social inclusion and social inequality (Instituto Brasileiro de Defesa do Consumidor [IDEC], 2004). Research has shown that consumers are more likely to buy from corporations that are socially responsible (Maignan, 2001). The Brazilian Consumers Organisation (IDEC) defines Corporate Social Responsibility [CSR] as a permanent ethical position on the part of corporations in the market towards society. According to the Institute, CSR goes beyond social actions and philanthropy; social responsibility should be at the foundation of the enterprise's activity. IDEC postulates that CSR includes the concern for and the commitment to the impacts business causes on consumers, the environment and its employees. One of the more prominent CSR activities is CRM (Drumwright, 1996).

CRM-related studies were carried out in Brazil, approaching diverse perspectives such as the association between corporations, NGOs and the community (Wilner, Alves, \& Vasconcelos, 2007), theoretical frameworks (Vieira, Higuchi, Schneider-de-Oliveira, \& Corrêa, 2007), as well as, the relationship between consumers and corporations (Dantas, Lucas, Kishore, \& Andre, 2005; Ikeda, Campomar, \& Miura, 2000; Salgado, Penedo, Pretto, \& Pacagnella, 2007).

The contrast between the corporation's perception of CRM and what consumers demand from the corporation was what motivated the authors to study this subject. On the one hand the corporations use 
CRM to address their business objectives such as increased sales and profits and enhance their corporate reputation (Adkins, 2000). On the other hand, consumers demand more responsible actions from corporations. They are asking the corporations to be at least partially motivated by helping others and not to act completely out of self-interest (Mohr, Webb, \& Harris, 2001).

While being aware of the importance of consumers in this role, this study will focus on consumer perception regarding CRM and the impact it has on corporate reputation, thus adding further to the knowledge in this field. Given the increasing level of interest from consumers, society and business in the area of CSR, and in particular CRM, this study aims to examine how consumers respond to the campaigns within the South East of the UK. This study was part of a Master Degree thesis by one of the authors at the University of Brighton, UK. It aims to investigate whether consumers perceive the alliance between corporations and non-profit organisations as adding to corporate reputation.

\section{CAuse Related MARKeting [CRM]}

There are many terms similar to CRM. Among these are corporate societal marketing, corporate issue promotions, corporate social marketing, social issues marketing, pro-social marketing, and passion branding (Berglind \& Nakata, 2005).

However, CRM is the most suitable term for this subject. Varadarajan and Menon (1988), among the earliest writers on CRM, define it as:

The process of formulating and implementing marketing activities that are characterised by an offer from the firm to contribute a specified amount to a designated cause when customers engage in revenue-producing exchanges that satisfy organisational and individual objectives (Varadarajan \& Menon, 1988, p. 60).

Researchers suggest that when consumers are requested to evaluate CRM programmes they usually do so in a positive manner (Machado \& Damacena, 2006). These researchers also highlight some elements that can modify these same attitudes, such as the type of cause to be supported, the association between the cause and the business and the participation of the consumer, among others.

CRM is a well established marketing tool, being recognized as efficient since its introduction in the United States through an American Express campaign (Webb \& Mohr, 1998).

American Express first employed the concept of CRM in 1982 in the USA (Till \& Nowak, 2000). Each time someone used the card, 5 cents were donated to several arts organisations participating in the San Francisco Festival. It was a successful endeavour and encouraged the corporation to try similar actions on a national basis. In 1983, American Express developed the programme for the renovation of the Statue of Liberty, which was probably the first CRM programme to gain worldwide renown. Use of the card increased 28\% and US\$ 1.7 million was donated to the project (Adkins, 2000; Andreasen, 1996; Smith \& Higgins, 2000). The continuous growth occurring in this area is a result of the positive outcomes experienced by major corporations in their CRM programmes (Barone et al., 2000).

Drumwright (1994) argues that through CRM the company can increase its sales and market share, motivate its employees, improve its corporate and brand image and generate positive publicity.

Adkins (2000) postulates that CRM is not philanthropy, which expects nothing in return. From her point of view it is merely good business for both non-profit and for-profit organisations. CRM alliances should be a relationship of mutual benefit for the corporation, for the charity and for the cause. For the corporation, the benefits include an increase in brand awareness or even increased corporate profits. For the cause, the benefit comes in the form of increased contributions and generating more awareness. Furthermore, Pringle and Thompson (1999) perceive CRM as a marketing tool that associates a corporation with a cause for the benefit of both. This can come about through a 
relationship with a charity or by directly addressing the cause. The authors associate the rising consumer social awareness with the growth of CRM actions. They argue that consumers are purchasing products as a demonstration of their own social consciousness.

However, Varadarajan and Menon (1988) alert firms to the dangers. Regardless of increased sales and good publicity, firms can be perceived as exploiters of causes and charities, which can ultimately become bad publicity. Barone et al. (2000) claim that consumers may be sceptical about CRM and question whether the objective is to benefit the cause or the corporation. Alternatively, Polonsky and Wood (2001) suggest that the real motivation for a corporate donation is the perception of being a good corporate citizen. It can be said that CRM is part of a new trend in which corporations are embracing a socially responsible approach to their activities (Broderick et al., 2003). On the other hand, CRM is also perceived as a strategic marketing tool that can improve consumer perceptions regarding a firm (Cone et al., 2003; Polonsky \& Wood, 2001). As a consequence, CRM has been seen as a long-term activity (Cone et al., 2003).

Firms may still wish to demonstrate a high level of commitment to the cause, such as signing a fiveyear support agreement (Dean, 2003). However Till and Nowak (2000) declare that CRM is both strategic and tactical. From their perspective in a tactical approach a brand might embrace a cause for a restricted period of time. In contrast, the authors perceive the strategic approach as the core of brand positioning. As such, the alliance with the cause or non-profit organisation is a crucial factor for the brand identity. Broderick et al. (2003), counterbalancing this debate, postulate that effective CRM can influence consumer perception regarding an organisation and its products. Therefore, a number of corporations are shifting CRM from a short-term activity to a long-term strategic effort to build brand recognition and reputation. Porter and Kramer (2002) also argue about the benefits and the possibilities to acquire competitive advantage through corporate philanthropy, although the authors affirm that these benefits are improved when the philanthropic investments are aligned to the core business.

\section{CRM and the Benefits for Corporation, Non-profits and Consumers}

CRM is defined as a win-win-win situation (Adkins, 2000), providing a win for the charity or cause, a win for the consumer and a win for the business. Here, benefits for corporations, non-profit organisations and consumers are shown.

The most notable benefits for the corporation take place inside the corporation itself, concerning staff in the form of improved employee morale (Drumwright, 1996; Polonsky \& Wood, 2001; Wood, 1998) and loyalty (Cone et al., 2003; Wragg, 1994). With increased staff motivation, CRM can make employees more enthusiastic about their jobs (Cone et al., 2003) and constitutes a powerful internal marketing tool. Likewise, Roddick (1991) argues that the most remarkable positive point for engaging in social activities is the effect it has on the staff.

CRM can improve the corporation image (Broderick et al., 2003; File \& Prince, 1998; Kotler, 2003; Mason, 2002; Polonsky \& Wood, 2001). Andreasen (1996) believes that the non-profit image can define or enhance the corporate image. Cone et al. (2003) warn that CRM is not a solution for a damaged reputation. It is, however, a way to strengthen the strongest brands. It appears to be a new way of adding value to brands so as to satisfy growing consumer demands for demonstrations of social commitment (Pringle \& Thompson, 1999). CRM expresses corporation responsiveness to social concerns while raising funds for a good cause (Docherty \& Hibbert, 2003). Furthermore, CRM can enhance business credibility (Broderick et al., 2003) and corporate reputation (Cone et al., 2003).

Cravens, Oliver and Ramamoorti (2003) postulate that the most important strategic and durable asset that a corporation possesses is probably its reputation. Dolphin (2004) suggests that reputation is an intangible asset and as such is difficult to measure and replicate. Lewis (2003) claims that brand and reputation cannot be separated. In his opinion, brands are no longer perceived in the traditional marketing sense. 
Corporate reputation has been defined by Gotsi and Wilson (2001) as:

A stakeholder's overall evaluation of a corporation over time. This evaluation is based on the stakeholder's direct experiences with the corporation, any other form of communication and symbolism that provides information about the firm's actions and/or a comparison with the actions of other leading rivals (Gotsi \& Wilson, 2001, p. 28).

CRM programmes offer free publicity and PR while increasing sales and profits (Adkins, 2000; Cone et al., 2003; Mason, 2002; Polonsky \& Wood, 2001; Pringle \& Thompson, 1999; Wood, 1998) and also enhance customer loyalty (Broderick et al., 2003; Kotler, 2003). Corporations receive the added benefit of having access to customers, employees, trustees and donors from non-profit organisations (Andreasen, 1996).

In other perspective, benefits for non-profit organisations should be shown. Clearly, the single most important benefit that non-profits receive from a CRM programme comes in the form of financial resources (Cone et al., 2003; Polonsky \& Wood, 2001; Wood, 1998). In a partnership with firms, nonprofits are perceived as a strategic partner that is not limited to just asking for money and donations (Andreasen, 1996). In the same way, Sargeant (1999) suggests that CRM has switched the emphasis on what business can do for charity to an equal focus on what charity can do for business.

CRM generates free publicity and public awareness for both the cause and non-profit organisation (Docherty \& Hibbert, 2003; Wood, 1998). As a consequence, it can increase an organisation's volunteer numbers in the short term (Docherty \& Hibbert, 2003; Polonsky \& Wood, 2001). The nonprofit organisation can also receive help from the senior staff of the firms providing managerial assistance (Cone et al., 2003; Docherty \& Hibbert, 2003; Polonsky \& Wood, 2001). Therefore, in addition to financial gains, other important resources can be obtained, including professional skills, technical knowledge and such physical assets as distribution networks (Cone et al., 2003; Wood, 1998).

In conclusion, consumers also gain from CRM, as purchasing a product or service benefits a charity or cause. Thus, the consumer is helping society, giving him/her a feeling of satisfaction for doing some good (Bono, 1999 as cited in Pringle \& Thompson, 1999; Polonsky \& Wood, 2001). Consumers can either contribute to the society in which they live and work or be the direct beneficiary of the cause.

\section{RESEARCH METHODS}

The focus of this research is on consumer perceptions. Therefore, a consumer survey was conducted in order to examine how the alliance between for-profit and non-profit organisations is perceived among the residents of Brighton, in the southeast of England, UK. Brighton has approximately 200,000 inhabitants; it is a tourist resort, welcoming around 8 million tourists each year. The city has a high density of businesses involved in the media in general, particularly digital or new media companies and also in leisure. Brighton is an educational centre with two universities and many English language schools. As a result Brighton is well-known as a cosmopolitan city with a young population.

\section{Research Questions}

Based on the aims and CRM literature, the authors developed the following research questions:

CRM tends to be beneficial to non-profit organisations. Non-profits receive financial assistance, free publicity and PR, while raising awareness for their cause. The first question seeks to verify whether consumers accept such ideas: 


\section{Question I - Do consumers believe that Cause Related Marketing activities are beneficial to the non-profit organisation?}

Alternatively, CRM can threaten to commercialise non-profit organisations. CRM can also be perceived as exploiting worthwhile causes and charities. To verify whether consumers accept these ideas, the second research question was developed:

Question II - Do consumers believe that Cause Related Marketing activities do not benefit the non-profit organisation?

\section{Questionnaire Design}

In order to develop a questionnaire regarding the perception of CRM alliances between for profit and non-profit organisations by consumers, the researchers examined secondary data on the subject. Malhotra and Birks (2000) state that secondary data is fundamental to support, identify and analyse research problems and to formulate research design. The authors claim that it is a requirement for the collection of primary data. Moreover, theory provides a framework "for critically understanding the phenomena" (Silverman, 2000, p. 78). For the current research, a large number of sources were used as secondary data to provide an understanding of the context and define the main issues to be addressed in the questionnaire. The primary sources were journal articles, surveys and books.

The questionnaire utilised by this research started with a simple introduction explaining its nature and inviting the respondent's cooperation. Cooperation in surveys is voluntary and relies largely on the goodwill of the informants (Chisnall, 2001). The questionnaire has a mix of the two main types of questions that are largely utilised in surveys: open-ended questions and closed questions. An openended question requests personal answers whereas in closed questions the response is limited regarding the depth of response.

\section{Pilot Test}

Before the survey was carried out, the questionnaire was piloted in Brighton with 10 consumers, on $11^{\text {th }}$ August, 2004. Hague (1992) suggests that a pilot test is the best way to find out if the questionnaire serves its purpose. However, it must be carried out under the same conditions as the main research (Chisnall, 2001). To fulfil these requirements, the sample for the pilot test was six women and four men. A total of six respondents (4 women and 2 men) were between the ages of 30 and 59; and 4 respondents ( 2 women and 2 men) were between 20 and 29. While respecting these requirements, the selection of these interviewees was on the basis of convenience.

Following the pilot test, the questionnaire went through a number of alterations: some questions were rewritten; the sequence of the questions was changed; and multi-questions were constructed from answers derived from open-ended questions. As an example of this, the good causes that appeared in the questionnaire came from the respondents from the pilot test.

\section{Sampling and Data Collection}

The research utilised quota sampling. Chisnall (2001) postulates that quota sampling is a kind of judgment sampling in which selection is controlled to some extent with regard to gender, age etc. In order to minimize bias, the present survey utilised the same demographics of the Brighton population found in the 2001 census concerning gender and age. Thus, from a sample of 200 Brighton residents, $48 \%$ were male and $52 \%$ were female (see Table 1 ). In the same way, $1 / 3$ of the population was aged between 20 and 29, and 2/3 were between the ages of 29 and 59 (see Table 2). These age groups were chosen because the researchers wished to understand the perceptions of the adult population. 
Table 1: Census (Gender) x Sample to Be Surveyed

\begin{tabular}{|l||l||l|}
\hline & Resident population $(\%)$ & Numbers \\
\hline Gender & Resident of Brighton and Hove & Sample to be surveyed \\
\hline Male & $48 \%$ & 96 \\
\hline Female & $52 \%$ & 104 \\
\hline
\end{tabular}

Source: Office for National Statistics [ONS] (2001), current survey.

Table 2: Census (Age Group) x Sample to Be Surveyed

\begin{tabular}{|l|l||l|}
\hline & Resident population (\%) & Numbers \\
\hline Age & Brighton and Hove & Sample to be surveyed \\
\hline Under 16 & 16.6 & 0 \\
\hline 16 to 19 & 4.7 & 0 \\
\hline 20 to 29 & 17.0 & 66 \\
\hline 30 to 59 & 41.0 & 134 \\
\hline 60 to 74 & 12.0 & 0 \\
\hline 75 and over & 8.6 & 0 \\
\hline
\end{tabular}

Source: Office for National Statistics [ONS] (2001), current survey.

To fulfil these requirements, the researchers interviewed 227 consumers between $15^{\text {th }}$ August and $20^{\text {th }}$ September, 2004. A total of 27 were left out. Interviewees over 60 years were excluded, as were those under the age of nineteen. In the same way, the authors randomly excluded respondents when the quotas for each gender or age were surpassed.

The questionnaire was applied in personal, face-to-face interviews. Thus, primary data was gathered directly from each respondent (Chisnall, 2001).

\section{DATA ANALYSIS}

The data obtained through the closed questions were analyzed using statistics described by Fink (1995), as a way of organizing and interpreting numerical information. The researchers utilised the SPSS software program in order to facilitate the statistical analysis.

Open-ended questions were also analysed, in which new information that had not been seen in the closed questions could be found and developed. It is important to include open-ended questions due to this possibility for study enrichment.

\section{Charities and Good Causes}

A large proportion of the consumers in this survey think that it is a good idea (57.5\%) or a very good idea $(20.5 \%)$ for a charity or good cause to work with a corporations. Just $18 \%$ said it is a poor idea and few respondents (4\%) thought it a very poor idea. No statistical difference between genders was found concerning this issue, but a difference was found regarding age groups (see Table 3 ). As the p-value is $0.044(<0.05)$ (see Table 4), it can be said that although the younger age group perceives this partnership as beneficial to charities, the research demonstrated that a portion of the younger group regards it as a poor idea. Moreover, the percentage of younger consumers who share this 
opinion is more accentuated in comparison with the older age group. While $33.3 \%$ of the younger group consider the partnership either a poor idea or a very poor idea, just $16.4 \%$ of the group between 30 and 59 years of age share this same perception.

Table 3: Cross Tabulation - What Do You Think about Charities and Good Causes Working Together with a For-profit Corporation? x Age Group of Respondents

\begin{tabular}{|c|c|c|c|c|c|c|c|}
\hline & & & \multicolumn{4}{|c|}{$\begin{array}{l}\text { What do you think about charities and good } \\
\text { causes working together with a for-profit } \\
\text { corporation? }\end{array}$} & \multirow[t]{2}{*}{ Total } \\
\hline & & & $\begin{array}{l}\text { A very } \\
\text { good idea }\end{array}$ & $\begin{array}{ll}\text { A } & \text { good } \\
\text { idea }\end{array}$ & $\begin{array}{ll}\text { A } & \text { poor } \\
\text { idea }\end{array}$ & $\begin{array}{l}\text { A very } \\
\text { poor idea }\end{array}$ & \\
\hline \multirow{4}{*}{$\begin{array}{l}\text { Age group } \\
\text { of } \\
\text { respondent }\end{array}$} & \multirow[b]{2}{*}{$\begin{array}{l}30 \text { to } \\
59\end{array}$} & Count & 29 & 83 & 17 & 5 & 134 \\
\hline & & $\begin{array}{l}\% \text { within } \\
\text { age } \\
\text { group }\end{array}$ & $21.6 \%$ & $61.9 \%$ & $12.7 \%$ & $3.7 \%$ & $100.0 \%$ \\
\hline & $\begin{array}{ll}20 & \text { to } \\
29 & \end{array}$ & Count & 12 & 32 & 19 & 3 & 66 \\
\hline & & $\begin{array}{l}\% \text { within } \\
\text { age } \\
\text { group }\end{array}$ & $18.2 \%$ & $48.5 \%$ & $28.8 \%$ & $4.5 \%$ & $100.0 \%$ \\
\hline \multirow{2}{*}{\multicolumn{2}{|c|}{ Total }} & Count & 41 & 115 & 36 & 8 & 200 \\
\hline & & $\begin{array}{l}\% \text { within } \\
\text { age } \\
\text { group }\end{array}$ & $20.5 \%$ & $57.5 \%$ & $18.0 \%$ & $4.0 \%$ & $100.0 \%$ \\
\hline
\end{tabular}

Table 4: Chi-square Tests

\begin{tabular}{|l|l|l|l|}
\hline & Value & df & $\begin{array}{l}\text { Asymp. Sig. } \\
(\text { 2-sided) }\end{array}$ \\
\hline Pearson Chi-Square & $8.093(\mathrm{a})$ & 3 & .044 \\
\hline Likelihood Ratio & 7.719 & 3 & .052 \\
\hline $\begin{array}{l}\text { Linear-by-Linear } \\
\text { Association }\end{array}$ & 3.645 & 1 & .056 \\
\hline N of Valid Cases & 200 & & \\
\hline
\end{tabular}

a 1 cells $(12.5 \%)$ have expected count less than 5. The minimum expected count is 2.64 .

When consumers were asked the reasons for their opinion, $47 \%$ replied that the non-profits receive financial assistance, followed by both charities and corporation benefit with $17 \%$ and raises awareness/publicity to the cause in third place with $16.5 \%$ (see Table 5). 
Table 5: Can You Give the Reason for Your Opinion? (Follow-up Question to 'What Do You Think about Charities and Good Causes Working Together with a for Profit Corporation?’)

\begin{tabular}{|c|c|c|c|c|c|}
\hline & & Frequency & Percent & $\begin{array}{l}\text { Valid } \\
\text { Percent }\end{array}$ & $\begin{array}{l}\text { Cumulative } \\
\text { Percent }\end{array}$ \\
\hline \multirow{8}{*}{ Valid } & \begin{tabular}{|l|} 
Financial \\
support
\end{tabular} & 94 & 47.0 & 47.0 & 47.0 \\
\hline & $\begin{array}{l}\text { Managerial } \\
\text { support }\end{array}$ & 2 & 1.0 & 1.0 & 48.0 \\
\hline & $\begin{array}{l}\text { Increase } \\
\text { publicity/aware } \\
\text { ness for cause } \\
\text { and corporation }\end{array}$ & 33 & 16.5 & 16.5 & 64.5 \\
\hline & $\begin{array}{l}\text { Immoral to } \\
\text { exploit charities }\end{array}$ & 20 & 10.0 & 10.0 & 74.5 \\
\hline & Help society & 10 & 5.0 & 5.0 & 79.5 \\
\hline & \begin{tabular}{|l|} 
Charities and \\
corporations \\
will benefit \\
\end{tabular} & 34 & 17.0 & 17.0 & 96.5 \\
\hline & $\begin{array}{l}\text { Consumers will } \\
\text { have a good } \\
\text { impression of } \\
\text { the firms }\end{array}$ & 7 & 3.5 & 3.5 & 100.0 \\
\hline & Total & 200 & 100.0 & 100.0 & \\
\hline
\end{tabular}

Consumers who thought the link between corporations and non-profit organisations was a good or very good idea shared the opinion that it was a good way to raise money for charities:

"Makes for a better/more equal society" (Respondent 24).

"It's a good way for corporations to give money to charities and good causes" (Respondent 59).

They also stated that both the cause/non-profit and the corporation benefit from such an association:

"A corporation can improve its image and the charity can get the money" (Respondent 77).

"Brings a positive image to the corporation" (Respondent 128).

Conversely, respondents who had a poor perception regarding the association between for-profit and non-profit organisations had more critical views. They mentioned that it is immoral to exploit charities:

“Corporations shouldn't make money because of the public's sympathies" (Respondent 139).

"Consumers will have good impressions of the corporation so they can sell more products" (Respondent 89).

"Because the corporations just want to increase their profits" (Respondent 102).

Such consumers believe that while non-profits may receive money from corporations, only small amounts are given. In their own words:

"Just a little of the money goes to charity" (Respondent 196).

Reinforcing the majority of consumer opinions that consider the partnership between for-profit and non-profit organisations as a good idea, Christopher Holmes, the Research and Development Manager at Business in the Community, believes that the partnership is a win-win situation. He suggests that CRM is a decisive component of the non-profit fundraising mix, and the main charity benefits include 
increasing funds, improving awareness, building and enhancing the brand, promoting understanding and communicating new messages.

The good causes consumers most want to support are children, indicated by $38.5 \%$, followed by health research, with $21.5 \%$. No statistical difference was found between genders or age groups. However, the researchers observed that the choice of the cause tended to have a particular motivation. For instance, one respondent who chose health research explained that her mother had breast cancer. Thus, she felt better about this kind of charity. Similar cases appeared throughout the research project, with several respondents giving personal reasons for supporting a cause. Respondents generally took a longer time to answer this question, saying that it was very difficult to choose just one cause. The results are displayed in Figure 1.

Figure 1: Which of these Causes Would You Like to Support Most?

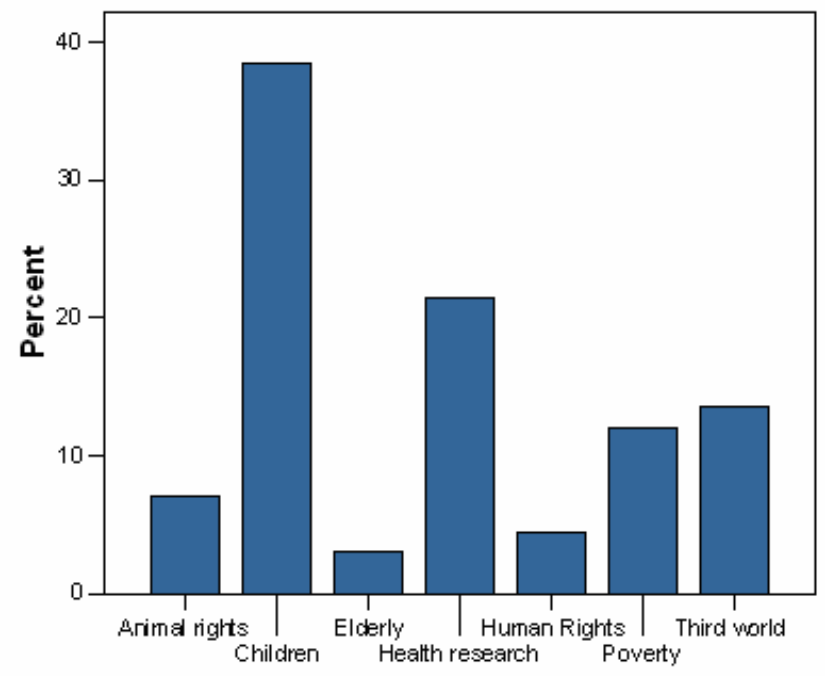

Based on these findings, the understanding is that consumers consider it a good idea for non-profit organisations to work with a corporations. They think this primarily because they agree that it is a good way for charities and good causes to receive financial assistance from corporations. Regarding the cause respondents most wanted to support, the majority chose children. Nevertheless, as mentioned above, the researchers observed that preference for a particular cause may have a personal motivation.

\section{Evaluation of the Research Questions}

In this section, the research questions developed by this study were answered. Two hundred consumers, both male and female, from two different age groups in the Brighton area took part in the survey. In addition, the researchers also interviewed the Research Manager from Business in the Community and analysed published data, especially corporate reports form corporations mentioned by the consumers. Based on the findings of this study, the research questions were answered within the consumers' perspectives regarding CRM and non-profit organisations.

\section{Question I - Do consumers believe that Cause Related Marketing activities are beneficial to the non-profit organisation?}

The respondents in the present research survey believed that Cause Related Marketing activities are beneficial to the non-profit organisation. This was based on evidence that $78 \%$ of the consumers understand that a partnership between for-profit and non-profit organisations is good for the nonprofits. They justified this principally by the fact that charities receive financial assistance and enhance 
cause awareness. This finding reinforces the works of Polonsky and Wood (2001), Cone et al., (2003) and Wood (1998) who state that the most important benefit comes in form of financial resources.

Interestingly, $76 \%$ of the respondents bought products/service linked with charities and good cause primarily to help the charities. This finding goes beyond the corporation's benefits state in the revised literature as it is exactly a benefit in the traditional marketing sense. What could be inferred from this particular finding is that apart from reputational gains or branding reinforcements, $76 \%$ of the consumers interviewed bought products or services in order to help charities.

\section{Question II - Do consumers believe that Cause Related Marketing activities do not benefit the non-profit organisation?}

Only a minority of the consumers who took part in this survey did not believe that Cause Related Marketing is beneficial to the non-profit organisation. These respondents $(22 \%)$ argued that it is immoral to exploit charities and that non-profits only receive a small portion of the money generated. This finding corroborates the results from the findings of Silva, Wanderley, Sousa and Lucian (2007), which highlight five major ethical conflicts including the portion of the money that actually reaches the charities.

After evaluating the research questions, it can be concluded that the majority of consumers are aware of CRM programmes and perceive them as beneficial to non-profit organisations. More importantly, $76 \%$ of them bought products/services linked with charities and good causes primarily to help the charities. As such, the corporations are gaining not only in reputational terms, but also in profitable terms. This finding is an important one as it goes beyond what is stated in the literature. The consumer perception is ratified by the corporations that consider CRM activities as capable of enhancing their reputation and brand value, although corporations do not state their financial gain as a CRM outcome.

\section{CONCLUSION}

This study found that consumers have a better perception of firms that work with charities and good causes. However, they are aware that corporations themselves benefit from this partnership. They also consider that the partnership between corporations and charities contributes to society, and believe this contribution could be higher, categorizing it currently as having a merely medium impact.

The respondents view working with a corporations as beneficial to non-profit organisations. They agree this is a good way for charities and good causes to receive financial assistance from corporations, and that such partnerships increase publicity and awareness for the charity and good cause. Regarding charities, consumers put a priority on supporting good causes related to Children. Those associated with Health Research came in second in order of preference, followed by those linked to the Third World. Despite these results, the researchers noticed that individual connection with a cause might have considerably influenced consumer attitudes and behaviour in relation to a specific cause.

We found that CRM can induce consumers to switch brands as well as increase spending as respondents have purchased products or services linked to charities and good causes.

According to our findings, we can conclude that the majority of consumers view interaction between for-profit and non-profit organisations in a positive light. Therefore, we can affirm that through the CRM programs, corporations can obtain benefits related to reputation and image, which are considered valuable assets. Non-profit organisations can also obtain benefits when they receive financial or technological resources, among others, and with those resources they can contribute to the improvement of the society. Therefore, the interaction between for-profit and non-profit organisations 
through CRM programs can create competitive advantage and benefits to all those involved, including society.

However, it is important to mention that there are some recommendations for increasing the potential of the benefits of CRM, not only for corporations but also to the non-profit organisations. Those recommendations can be seen in the following section.

\section{Recommendations}

Based on the main findings of this research, the researchers formulate the following recommendations:

\section{For Profit-making Organisations}

Corporations should monitor the results obtained by charities and good causes and post these results on their websites and in their PR to consumers, as well as to the Consumer Association. Transparent CRM programmes achieve more credibility for corporations in the perception of consumers.

Corporations should inform consumers as to what percentage of the product price is earmarked for the charity. Regarding voucher schemes, consumers should be informed as to how many are necessary for the benefits to be received. Such actions reinforce the credibility of CRM programmes.

Corporations should affiliate themselves with a good cause or charity in a long-term partnership. This helps to demonstrate a true commitment to the cause or charity.

Corporations should invest in communication campaigns focusing on younger consumers (20 to 29 years of age), demonstrating that corporations can be both profitable and ethical, as these are not necessarily diametrically opposed characteristics. In fact, bigger corporations can make larger donations.

Corporations should select charities or good causes that are related to their business activities and with which their consumers can work. Higher affinity between business and non-profits will generate better results for both.

\section{For Non-profit Making Organisations}

Non-profits should conduct extensive research on the corporation that it is planning to have as a partner. Preference should be given to corporations with similar objectives, whereas corporations with bad reputations should be avoided.

Non-profits should communicate through newsletters or websites to inform donors and clients of the CRM programmes in which they are taking part and what benefits they will receive from the partnership.

\section{Research Limitations and Suggestions for Future Research}

This study has attempted to provide an understanding of consumer perceptions regarding CRM and its main programmes in the UK. Further research should therefore consider the following points. This research interviewed only consumers in the Brighton area (southeast of England, UK). Future research could expand the data collection to other towns/cities in the UK in order to carry out a comparative study. This research investigated the perceptions of ordinary consumers regarding CRM. Further research could be carried out with consumers who have already taken part in a CRM programme. Future research could be done with a primary focus on the Consumer Association to investigate how it evaluates CRM programmes and how the Consumer Association influences the average consumer. 
Further research can be carried out to explore the perspective of non-profits regarding the impact CRM has on the organisation.

\section{REFERENCES}

Adkins, S. (2000). Cause related marketing: who cares wins. Oxford: Elsevier ButterworthHeinemann.

Andreasen, A. R. (1996). Profits for non-profits: find a corporate partner. Harvard Business Review, 74(6), 47-59.

Barone, M. J., Miyazaki, A. D., \& Taylor, K. A. (2000). The influence of cause-related marketing on consumer choice: does one good turn deserve another? Journal of the Academy of Marketing Science, 28(2), 248-262.

Berglind, M., \& Nakata, C. (2005). Cause-related marketing: more buck than bang? Business Horizons, 48(5), 443-453.

Broderick, A., Jogi, A., \& Garry, T. (2003). Tickled pink: the personal meaning of cause-related marketing for customers. Journal of Marketing Management, 19(5), 583-610.

Brown, T. J., \& Dacin, P. A. (1997). The company and the product: corporate associations and consumer product responses. Journal of Marketing, 61(1), 68-84.

Business in the Community. (2003). Cause related marketing tracker. Retrieved March 22, 2004, from http://www.bitc.org.uk/programmes/programme_directory/cause_related_marketing/cmtracker. html

Chisnall, P. (2001). Marketing research (6th ed.). London: McGraw-Hill.

Cone, C. L., Feldman, M. A., \& DaSilva, A. (2003). Causes and effects. Harvard Business Review, 81(7), 95-101.

Cravens, K., Oliver, E. G., \& Ramamoorti, S. (2003). The reputation index: measuring and managing corporate reputation. European Management Journal, 21(2), 201-212.

Dantas, S. S., Lucas, A. C., Kishore, A., \& Andre, C. B. (2005). Estudo do comportamento do consumidor em uma loja de produtos socialmente responsáveis. Proceedings of the Seminário de Administração, São Paulo, SP, Brazil, 8.

Dean, D. H. (2003). Consumer perception of corporate donations: effects of company reputation for social responsibility and type of donation. Journal of Advertising, 32(4), 91-104.

Docherty, S., \& Hibbert, S. (2003). Examining company experiences of a UK cause-related marketing campaign. International Journal of Nonprofit and Voluntary Sector Marketing, 8(4), 378-389.

Dolphin, R. R. (2004). Corporate reputation: a value creating strategy. Corporate Governance: International Journal of Business in Society, 4(3), 77-92.

Drumwright, M. E. (1994). Socially responsible organizational buying: environmental buying as a noneconomic buying criteria. Journal of Marketing, 58(3), 1-19.

Drumwright, M. E. (1996). Company advertising with a social dimension: the role of noneconomic criteria. Journal of Marketing, 60(4), 71-87. 
Endacott, R. W. J. (2004). Consumers and CRM: a national and global perspective. Journal of Consumers Marketing, 21(3), 183-189.

File, K. M., \& Prince, R. A. (1998). Cause related marketing and corporate philanthropy in the privately held enterprise. Journal of Business Ethics, 17(14), 1529-1539.

Fink, A. (1995). How to analyze survey data. London: Thousand Oaks Age.

Gotsi, M., \& Wilson, A. M. (2001). Corporate reputation: seeking a definition. Corporate Communications: An International Journal, 6(1), 24-30.

Hague, P. (1992). The industrial research handbook. London: Kogan Page.

Ikeda, A. A., Campomar, M. C., \& Miura, I. K. (2000). Combate ao desperdício de energia elétrica: uma caso de marketing societal. Revista de Administração da USP, 35(1), 5-13.

Instituto Brasileiro de Defesa do Consumidor. (2004). O consumidor e a responsabilidade social corporativa. Retrieved September 9, 2004, from http://www.idec.org.br/arquivos/guia_RSE.pdf

Kotler, P. (2003). Marketing management (11th ed.). New Jersey: Prentice Hall.

Lewis, S. (2003). Reputation and corporate responsibility. Journal of Communication Management, 7(4), 356-364.

Machado, S. K., \& Damacena, C. (2006). Percepção dos consumidores acerca do marketing relacionado a causas: uma revisão da literatura. Revista de Administração e Contabilidade da Unisinos, 3(2), 93-101.

Maignan, I. (2001). Consumer's perceptions of corporate social responsibilities: a cross-cultural comparison. Journal of Business Ethics, 30(1), 57-72.

Malhotra, N., \& Birks, D. (2000). Marketing research: an applied approach. London: Prentice Hall.

Mason, T. (2002, January 4). Good causes deliver for brands: do corporations gains from being socially responsible? Marketing, p. 11.

Mohr, L. A., Webb, D. J., \& Harris, K. E. (2001). Do consumers expect companies to be socially responsible? The impacts of corporate social responsibility on buying behaviour. Journal of Consumers Affairs, 35(1), 45-60.

Office for National Statistics. (2001). Census. Retrieved March 22, 2004, from http://www.statistics.gov.uk/census2001/get_facts.asp

Polonsky, M. J., \& Wood, G. (2001). Can the overcommercialization of cause-related marketing harm society? Journal of Macromarkerting, 21(1), 8-22.

Porter, M. E., \& Kramer, M. R. (2002). The competitive advantage of corporate philanthropy. Harvard Business Review, 80(12), 56-68.

Pringle, H., \& Thompson, M. (1999). Brand spirit: how cause related marketing builds brands. Chichester: John Wiley \& Sons.

Roddick, A. (1991). Body and soul: Anita Roddick with Russel Miller. London: Ebury Press.

Salgado, A. P., Jr., Penedo, A. S. T., Pretto, F. N., \& Pacagnella, A. C., Jr. (2007). O marketing socioambiental e o processo de decisão de compra dos consumidores finais: pesquisa exploratória no ponto de venda de empresas multinacionais supermercadistas de Ribeirão Preto - SP. Proceedings of the Seminário de Administração, São Paulo, SP, Brazil, 10. 
Silverman, S. (2000). Proposals that work: a guide for planning dissertations and grant proposals (4th ed.). London: Sage.

Sargeant, A. (1999). Marketing management for nonprofit organizations. New York: Oxford University Press.

Smith, W., \& Higgins, M. (2000). Cause-related marketing: ethics and the ecstatic. Business \& Society, 39(3), 304-322.

Silva, F. F. A., Wanderley, L. S. O., Sousa, J. M. Filho, \& Lucian, R. (2007). Ethics and cause related marketing: five major ethical conflicts. Proceedings of the Seminário de Administração, São Paulo, SP, Brazil, 10.

Till, B. D., \& Nowak, L. I. (2000). Toward effective use of cause-related marketing alliances. The Journal of Product \& Brand Management, 9(7), 472-484.

Varadarajan, P. R., \& Menon, A. (1988). Cause related marketing: a coalignment of marketing strategy and corporate philanthropy. Journal of Marketing, 52(3), 58-74.

Vieira, F. G. D., Higuchi, A. K., Schneider-de-Oliveira, R., \& Corrêa, P. S. A. (2007, setembro). Marketing social corporativo: estado da arte e proposição de um modelo conceitual. Anais do Encontro Nacional da Associação Nacional de Pós-Graduação e Pesquisa em Administração, Rio de Janeiro, RJ, Brazil, 31.

Webb, D., \& Mohr, L. A. (1998). A typology of consumer responses to cause-related marketing: from skeptics to socially concerned. Journal of Public Policy and Marketing, 17(21), 226-238.

Wilner, A., Alves, M. A., \& Vasconcelos, F. C. (2007, setembro). Comitê para democratização da informática (CDI): uma franquia social? Anais do Encontro Nacional da Associação Nacional de Pós-Graduação e Pesquisa em Administração, Rio de Janeiro, RJ, Brazil, 31.

Wood, G. (1998). Cause related marketing: caveat emptor? Proceedings of the Australia and New Zealand Marketing Academy Conference, Dunedin, New Zealand, 1.

Wragg, D. (1994). The effective use of sponsorship. London: Kogan Page.

Yechiam, E., Barron, G., Erev, I., \& Erez, M. (2002). On the robustness and the direction of the effect of cause-related marketing. Journal of Consumer Behaviour, 2(4), 320-330. 